\title{
The Danish Lithosphere Centre: a new earth science centre in Denmark
}

\author{
Hans Christian Larsen
}

Director, Danish Lithosphere Centre

The Danish Lithosphere Centre (DLC) is funded by the Danish National Research Foundation (DNRF) and was formed on 1 February, 1994 following a two year long planning and application phase. A total sum of 70 million Danish kroner has been granted to DLC over five years in order to carry out the research plan included in the original proposal. Extensive field programmes were initiated in 1994, and by end 1994 the centre was almost fully staffed. The general aim and format of the overall research plan of the centre are summarised below. The preliminary results of the 1994 work programmes are given by Marker et al. (this report) and Larsen et al. (this report).

\section{The centre}

DLC was established as an independent research unit hosted by the Geological Survey of Greenland (GGU) and the Geological Institute of the University of Copenhagen (GIKU). DLC access to administrative and laboratory facilities at GGU and GIKU and the costs for these services are covered by an aggreement between the Survey, the University, the Research Foundation and the director of the centre.

At the end of 1994, the centre employed ten geologists and geophysicists, one Ph.D. student (with the plan to have two more in 1995) and an administrative department leader. Twelve Research Fellows from GIKU and GGU are associated with the centre, and a total of about 15 international partners from USA, UK, Canada, Australia and the Netherlands are already active or will soon join in the DLC work. Research Fellows are staff members of the host institutions and the Geological Museum in Copenhagen who by agreement between the institutions and DLC are allotted research time to take part in DI C research programmes.

In 1994 substantial additional funding in support of the DLC research plan has been provided by the US National Science Foundation (NSF). A major deep crustal seismic study of the East Greenland margin (SIGMA) has been accepted by NSF for joint NSF-DLC funding in a collaboration between DLC and Woods Hole Oceanographic Institution, USA, and is scheduled for 1996. In addition, an $\mathrm{Ar} / \mathrm{Ar}$ age determination programme on the East Greenland Tertiary igneous province has been funded by NSF as a joint project between DLC and Oregon State University, USA.
The successful Ocean Drilling Program (ODP) Leg 152 in offshore South-East Greenland (Larsen et al., 1994b, c, d, e) provided an invigorating start to DLC's East Greenland activities and a new proposal to follow up on Leg 152 (Larsen et al., 1994a) has been accepted for realisation in 1995. This second ODP drilling leg (Leg 163) to SouthEast Greenland represents a major additional contribution to the DLC research plan.

\section{The DLC research plan}

The lithosphere, being in the order of $100 \mathrm{~km}$ thick, cannot for the most part be studied directly. To circumvent this problem it is necessary to apply methods such as: (1) geological studies of originally deep-seated rocks later exhumed and exposed at the surface by uplift and erosion processes; (2) seismology; (3) studies of the ways in which the lithosphere reacts to stress; or (4) studies of magmatic rocks which have their origin either below the lithosphere (in the asthenosphere) or in the deep lithosphere itself.

The DLC research plan builds on the application of such multi-disciplinary studies on selected geological problems of plate tectonic scale and significance. For the first five years of the centre's activities, the following two major topics have been selected:

- Amalgamation of Archaean continents into the Early Proterozoic North American/Atlantic craton as illustrated by the Nagssugtoqidian orogen in West Greenland (Fig. 1 in Marker et al., 1995).

- Formation of the Tertiary volcanic rifted margin in East Greenland during the continental break-up of the northern North Atlantic (Fig. 1 in Larsen et al., 1995).

The overall aim of the Nagssugtoqidian project is to carry out a comprehensive study of the architecture and dynamics of an Early Proterozoic collisional orogen. The research involves a wide range of techniques, and the goal is to describe the geodynamic evolution of the orogen in terms of plate tectonic processes. The study will be supplemented with geophysical studies at a later stage.

The Nagssugtoqidian orogen was chosen for this study because West Greenland offers excellent exposures, and a wide range of terranes and features common to most deeply eroded orogens developed in and adjacent to 
Archaean rocks which range back in time to the Early Archaean. In addition, the Nagssugtoqidian orogen occupies a central position in a larger trans-Atlantic Early Proterozoic orogenic belt which extends from north-eastern Canada over West and East Greenland into the northern Baltic Shield. West Greenland thus provides a key site for studies of crustal evolution through the Archaean, as well as for the subsequent Early Proterozoic orogenesis and assembly of crustal plates into larger continental masses analogous to Phanerozoic orogens.

The East Greenland margin project addresses the onshore as well as offshore elements of a rifted continental margin. In addition to geological field work, it involves extensive geophysical studies and offshore drilling (ODP). Deep continental drilling is suggested for a later phase of this study.

In recent years, it has been recognised that rifted margins show great variability despite being products of the same plate tectonic phenomena. In particular, many margins show evidence for intense magmatism with extremely large volumes of extrusives at the time of break-up (Coffin \& Eldholm, 1992, 1993). Examples of the latter include some of the world's largest flood basalt provinces as well as offshore accumulations of thick lava sequences, the so-called seaward-dipping reflector sequences (SDRS). The outbursts of volcanism at these volcanic rifted margins have proved difficult to explain without invoking anomalous hot asthenosphere, possibly sourced by mantle plumes. The overall aim of the East Greenland margin project is to study and understand the composition and thermal stage of the asthenosphere and the deformation of the lithosphere during continental break-up and formation of volcanic rifted margins.

For a number of reasons, the South-East Greenland margin is particularly well suited for the testing of various models for volcanic rifted margin formation. The SouthEast Greenland margin is close to a well-known and well constrained hot-spot (Iceland) and is part of the North Atlantic Tertiary province, which is counted among the world's most voluminous magmatic events (Coffin \& Eldholm, 1992, 1993). Furthermore, the margin is not segmented by major transform faults and the adjacent seafloor spreading pattern is simple and it is relatively undisturbed by Mesozoic rifting prior to break-up. The margin is relatively young and notably sediment-starved allowing for unique correlation possibilities between onshore and off- shore areas and part of the margin has been uplifted since break-up allowing direct examination of the crust from mid-crustal levels to the top of the continental flood basalts. Finally, all the main constituents of a volcanic rifted margin are present along the South-East Greenland margin (flood basalts, sills, dyke swarms, and seaward dipping reflector sequences).

In 1994 the centre started investigations in the study areas described above. The work involved substantial geological field work in both West and East Greenland as well as geophysical work offshore South-East Greenland. A total of 33 geologists and geophysicists participated in the work, including 9 DLC research staff members, 9 DLC Research Fellows and 15 international DLC research partners.

\section{References}

Coffin, M. F. \& Eldholm, O. 1992: Volcanism and continental break-up: a global compilation of large igneous provinces. In Storey, B. C., Alabaster, T. \& Pankhurst, R. J. (ed.) Magmatism and the causes of continental break-up. Geol. Soc. London Spec. Publ. 68, 17-30.

Coffin, M. F. \& Eldholm, O. 1993: Scratching the surface: estimating dimensions of large igneous provinces. Geology 21, 515-518.

Larsen, H. C., Brooks, C. K., Cox, K. G., Holm, P.-M., DahlJensen, T., Duncan, R., Fitton, G., Karson, J., Larsen, L. M., Nielsen, T. F. D., Saunders, A. D. \& Storey, M. 1994a: Proposal for drilling at the Southeast Greenland volcanic rifted margin. JOIDES Office, ODP Drilling Proposal 460.

Larsen, H. C., Saunders, A. D., Clift, P. \& ODP Leg 152 Scientific Party 1994b: Drilling unearth 'Fire and Ice' at the Southeast Greenland margin. Eos 75, 403-406.

Larsen, H. C., Saunders, A.D., Clift, P. \& ODP Leg 152 Party 1994c: Initial Report, ODP Leg 152. College Station: Texas A \& M University, 977 pp.

Larsen, H. C., Saunders, A. D., Clift, P., Beget, J., Wei, W., Spezzaferri, S. \& ODP Leg 152 Party 1994d: Seven million years of glaciation in Greenland. Science 264, 952-955.

Larsen, H. C., Saunders, A. D., Larsen, L. M., Lykke-Andersen, H., ODP Leg 152 Scientific Party, Marcussen, C. \& Clausen, L. 1994e: ODP activities on the South-East Greenland margin: Leg 152 drilling and continued surveying. Rapp. Grønlands geol. Unders. 160, 73-79.

H. C. L., Danish Lithosphere Centre, Øster Voldgade 10, DK1350 Copenhagen K, Denmark 